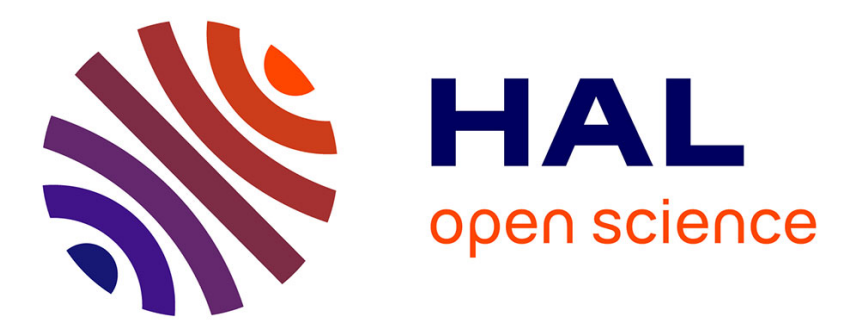

\title{
Cobalt-catalyzed versus uncatalyzed intramolecular Diels-Alder cycloadditions
}

Bohdan Biletskyi, Alphonse Tenaglia, Hervé Clavier

\section{To cite this version:}

Bohdan Biletskyi, Alphonse Tenaglia, Hervé Clavier. Cobalt-catalyzed versus uncatalyzed intramolecular Diels-Alder cycloadditions. Tetrahedron Letters, 2018, 59 (2), pp.103 - 107. 10.1016/j.tetlet.2017.11.052 . hal-01768362

\section{HAL Id: hal-01768362 \\ https://hal.science/hal-01768362}

Submitted on 18 Apr 2018

HAL is a multi-disciplinary open access archive for the deposit and dissemination of scientific research documents, whether they are published or not. The documents may come from teaching and research institutions in France or abroad, or from public or private research centers.
L'archive ouverte pluridisciplinaire HAL, est destinée au dépôt et à la diffusion de documents scientifiques de niveau recherche, publiés ou non, émanant des établissements d'enseignement et de recherche français ou étrangers, des laboratoires publics ou privés.

\section{(1) (1) $\$$}

Distributed under a Creative Commons Attribution - NonCommercial - NoDerivatives 44.0 


\section{Graphical Abstract}

To create your abstract, type over the instructions in the template box below.

Fonts or abstract dimensions should not be changed or altered.

Cobalt-Catalyzed Versus Uncatalyzed Intramolecular Diels-Alder Cycloadditions

Bohdan Biletskyi, Alphonse Tenaglia, Hervé Clavier

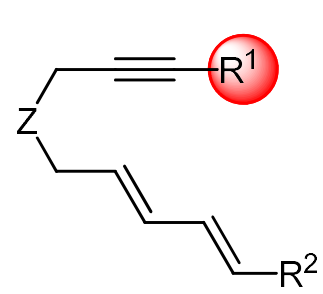

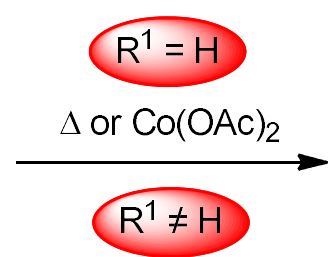

$\mathrm{Col}_{2}, \mathrm{dppe}, \mathrm{Zn}, \mathrm{Znl}_{2}$
Leave this area blank for abstract info.<smiles>[R]C1=C2C[Z]CC2C=CC1[R]</smiles> 


\title{
Cobalt-Catalyzed Versus Uncatalyzed Intramolecular Diels-Alder Cycloadditions
}

\author{
Bohdan Biletskyi ${ }^{\mathrm{a}}$, Alphonse Tenaglia ${ }^{\mathrm{a}}$ and Hervé Clavier ${ }^{\mathrm{a}}{ }^{*}$ \\ a Aix Marseille Univ, CNRS, Centrale Marseille, iSm2, Marseille, France
}

ARTICLE INFO

Article history:

Received

Received in revised form

Accepted

Available online

\section{Keywords:}

Cobalt

Cycloaddition

Cycloisomerization

Dienyne

Carbocycle
ABSTRACT

The intramolecular [4+2] cycloadditions of dienynes was investigated using cobalt-based catalysts. Substrates without substitution on alkyne moiety were found to react under thermal activation. The use of a cobalt salt as catalyst made reactions cleaner by limiting the formation of byproducts. Cycloadditions with dienynes possessing a substituent on the alkyne pattern occurred only in presence of a cobalt catalyst which displayed a moderate to good activity depending on the substrate patterns.
Cycloisomerizations are valuable transformations to prepare straightforwardly cyclic, bicyclic or polycyclic compounds from simple and readily available acyclic materials. ${ }^{1}$ Moreover, they belong to the class of atom-economy processes since no formal gain or loss of any atom takes place. ${ }^{2}$ However they are generally promoted by transition metals which allow to activate polyunsaturated substrates and trigger the formation of the new $\mathrm{C}-\mathrm{C}$ bonds under mild reaction conditions. ${ }^{3,4}$ For example, the intramolecular [4+2] cycloaddition of dienynes was successfully investigated with various transition metals (Scheme 1). Wender reported first an efficient $\mathrm{Ni}(0)$-based catalytic system under mild reaction conditions which unfortunately gave a rather modest endo/exo preference $(1.8-2.2 / 1) .^{5}$ Shortly after, Livinghouse demonstrated that $\mathrm{Rh}(\mathrm{I})$-based catalysts showed an even better efficiency since [4+2] cycloadducts were isolated with good to excellent diastereoselectivity ${ }^{6}$ and the use of chiral phosphines allowed to perform this transformation in an enantioselective fashion. ${ }^{7}$ Then, efforts focused on the study and improvement of $\mathrm{Rh}$-catalysis, ${ }^{8}$ and the transposition to iridium-catalysis did not led to better results. ${ }^{9}$ Recently, Chung reported that [4+2] cycloadditions of dienynes can be achieved at room temperature with a gold(I) catalyst but only for substrates featuring terminal alkynes $\left(\mathrm{R}^{2}=\mathrm{H}\right){ }^{10}$

Given the costs associated with the use of noble transition metals and chiral phosphines, it will be interesting to develop a new catalytic system for this transformation based on an earth abundant transition metal. Considering that cobalt showed a good ability to catalyze various cycloadditions, ${ }^{11}$ it seems to be a good candidate to investigate. Of note, whereas several examples of cobalt-mediated intermolecular [4+2] cycloadditions have been reported in the literature, ${ }^{12}$ to the best of our knowledge, no

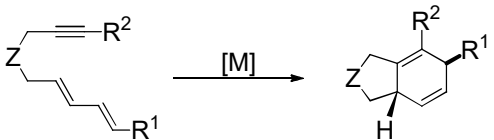

$$
\begin{aligned}
& {[\mathrm{M}]=[\mathrm{Ni}], \text { Wender } 1989} \\
& {[\mathrm{M}]=[\mathrm{Rh}], \text { Livinghouse 1990, Gilbertson } 1998} \\
& {[\mathrm{M}]=[\mathrm{Ir}], \text { Shibata } 2002} \\
& {[\mathrm{M}]=[\mathrm{Au}], \text { Chung } 2011} \\
& {[\mathrm{M}]=[\mathrm{Co}], \text { This work }}
\end{aligned}
$$

Scheme 1. Transition metal-promoted intramolecular DielsAlder cycloadditions of dienynes.

intramolecular Diels-Alder cycloadditions have been described so far. ${ }^{13}$

Based on our previous studies on the cobalt-mediated [6+2] cycloaddition between cycloheptatriene and $2 \pi$-partners (alkynes or allenes), ${ }^{14}$ we started to explore the cycloaddition of dienyne 1a with $\mathrm{CoI}_{2}$ as cobalt source, 1,2-bis(diphenylphoshino)ethane (dppe), zinc metal as reducing agent and $\mathrm{ZnI}_{2}$ as Lewis acid (Table 1, entry 1). With this catalytic system, at $80{ }^{\circ} \mathrm{C}$ in dichloroethane, after $20 \mathrm{~h}$ of reaction, $34 \%$ of the expected [4+2] cycloadduct 2a was isolated (entry 1). Pleasingly, the reaction proceeded with a high diastereoselectivity, and tipycally $\mathbf{2 a}$ was isolated with high diastereomeric ratio $>20: 1 .^{15}$ Importantly, the solvent needed to be degassed to avoid the formation of substantial amounts of dimerization products ${ }^{16}$ or oxidized product 3a. In the absence of $\mathrm{ZnI}_{2}$, the catalytic system performed better and $60 \%$ of $2 \mathbf{a}$ was isolated (entry 2). Then, many bidentate ligands were tested, among them dppe, 1,2bis(diphenylphoshino)methane (dppm) or 1,10-phenanthroline (entries 2-4) but only minor changes in chemical yields and

* Corresponding author. Tel.: +0-000-000-0000; fax:+0-000-000-0000; e-mail: author@university.edu 
Table 1. Optimization of reaction conditions for the cobaltmediated [4+2] cycloaddition ${ }^{\mathrm{a}}$

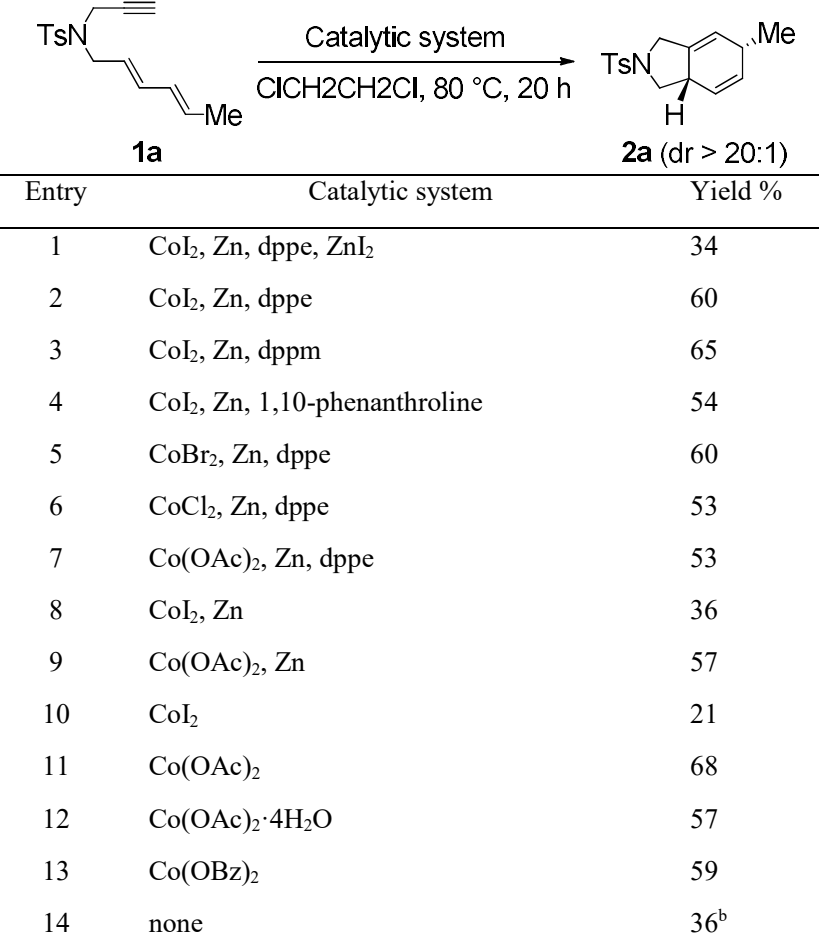

${ }^{a}$ Conditions: [Co] (5 mol\%), $\mathrm{Zn}(15 \mathrm{~mol} \%)$, Ligand (5 mol\%), $\mathrm{ZnI}_{2}$ (10 mol\%), dienyne 1a $(0.5 \mathrm{mmol}), \mathrm{ClCH}_{2} \mathrm{CH}_{2} \mathrm{Cl}(2 \mathrm{~mL}), 80^{\circ} \mathrm{C}, 20 \mathrm{~h}$.

${ }^{\mathrm{b}} 41 \%$ of oxidized product $3 \mathrm{a}$ was also isolated.<smiles>Cc1ccc2c(c1)CN([Te])C2</smiles>

diastereoselectivies were observed. As an additional evidence of the little impact of the ligand structure, when chiral ligands were used no chiral induction was detected. ${ }^{17}$ The nature of the cobalt(II) source was also found to be a minor parameter since only little differences were obtained with $\mathrm{CoI}_{2}, \mathrm{CoBr}_{2}, \mathrm{CoCl}_{2}$ and $\mathrm{Co}(\mathrm{OAc})_{2}$ (entries 2, 5-7). As the ligand structure did not impact significantly the course of the reaction, we carried out experiments without ligands (entries 8 and 9). Surprisingly, the catalytic system $\mathrm{Co}(\mathrm{OAc})_{2}$ and zinc metal performed well with the formation of $57 \%$ of $\mathbf{2 a}$. Control experiments without reducing agent were also achieved (entries 10-13). Whereas in the case of $\mathrm{CoI}_{2}$ the yield slightly decreased, with $\mathrm{Co}(\mathrm{OAc})_{2}$ a significant improvement was observed and $68 \%$ of $\mathbf{2 a}$ was isolated. $\mathrm{Co}(\mathrm{OAc})_{2} \cdot 4 \mathrm{H}_{2} \mathrm{O}$ and $\mathrm{Co}(\mathrm{OBz})_{2}$ exhibited somewhat lower activities. Importantly, we performed a control experiment without catalyst and, at $80{ }^{\circ} \mathrm{C}, 36 \%$ of cycloadduct $2 \mathrm{a}$ with an excellent diastereoselectivity $(\mathrm{dr}>20: 1)$ along with $41 \%$ of $\mathbf{3 a}$ (entry 14) ${ }^{18}$ Of note, in the reactions carried out in presence of cobalt, less than $10 \%$ of $\mathbf{3 a}$ was generally observed. The oxidation process affording 3a took place only during the reaction, since the purification step did not increase its quantity and cyclohexadiene derivatives were found stable in solution few days at room temperature. Thus, it appeared that the use of $\mathrm{Co}(\mathrm{OAc})_{2}$ allowed to reduce the oxidation process more than improve the reaction itself.

Then, we started to compare the uncatalyzed and cobalt-mediated intramolecular Diels-Alder cycloadditions of various dienynes featuring a terminal alkyne $\mathbf{1}$ (Table 2). Both reaction conditions gave [4+2] cycloadducts $\mathbf{2}$ with high diastereoselectivities. Compared to 1a, $C$ - and $O$-tethered dienynes were found less reactive. For example, $\mathbf{1 b}$ gave only $11 \%$ of corresponding cycloadduct $\mathbf{2 b}$ under thermal activation along with $22 \%$ of $\mathbf{3 b}$. In presence of $\mathrm{Co}(\mathrm{OAc})_{2}$, the reaction performed better with less oxidation competing (entries 3 and 4). Similar results were obtained with dienyne $1 \mathrm{c}$ to the exception that this time the use of

Table 2. Comparison between uncatalyzed and cobalt-mediated intramolecular Diels-Alder cycloadditions of various dienynes $\mathbf{1}^{\mathrm{a}}$
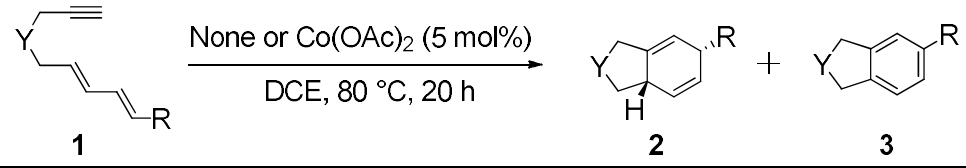

\begin{tabular}{|c|c|c|c|c|c|c|}
\hline \multirow[b]{2}{*}{ Entry } & \multirow[b]{2}{*}{ Substrate } & \multirow[b]{2}{*}{ Catalyst } & \multicolumn{4}{|c|}{ Products } \\
\hline & & & [4+2] Cycloadduct $2^{\mathrm{b}}$ & Yield (\%) & Oxidized product 3 & Yield (\%) \\
\hline 1 & & None & & 36 & & 41 \\
\hline 2 & & $\mathrm{Co}(\mathrm{OAc})_{2}$ & $2 a(d r>20: 1)$ & 68 & $3 a$ & $<10$ \\
\hline 3 & & None &. $\mathrm{Me}$ & 11 & $\mathrm{MeO}$ & 22 \\
\hline 4 & 10 & $\mathrm{Co}(\mathrm{OAc})_{2}$ & $2 b(d r>20: 1)$ & 27 & $3 b$ & $<10$ \\
\hline 5 & & None & & 11 & & 21 \\
\hline 6 & 1c & $\mathrm{Co}(\mathrm{OAc})_{2}$ & 2c $(d r>20: 1)$ & 23 & & 31 \\
\hline 7 & & None & & 60 & & 15 \\
\hline 8 & 1d & $\mathrm{Co}(\mathrm{OAc})_{2}$ & $2 d(d r>20: 1)$ & 60 & $3 d$ & $<10$ \\
\hline 9 & & None & & 63 & & 17 \\
\hline 10 & $1 \mathrm{e}$ & $\mathrm{Co}(\mathrm{OAc})_{2}$ & $2 e(d r>20: 1)$ & 68 & $3 e$ & 12 \\
\hline
\end{tabular}

${ }^{\mathrm{a}}$ Conditions: $\mathrm{Co}(\mathrm{OAc})_{2}(4.4 \mathrm{mg}, 5 \mathrm{~mol} \%)$, dienyne 1 (0.5 mmol), $\mathrm{ClCH}_{2} \mathrm{CH}_{2} \mathrm{Cl}(2 \mathrm{~mL}) 80{ }^{\circ} \mathrm{C}, 20 \mathrm{~h}$.

${ }^{\mathrm{b}}$ Major diastereomer depicted. 
$\mathrm{Co}(\mathrm{OAc})_{2}$ improved yields of both cycloadduct and oxidized product (entries 5 and 6). Better outcomes were obtained for dienynes 1d and 1e bearing a phenyl substituent at the terminal position of the dienic moiety but no significant difference between uncatalyzed and cobalt-catalyzed reactions could be noticed (entries 7-10).

When the dienyne 4a with a methyl substituent on the alkyne pattern was tested no reaction occurred either under thermal conditions nor in presence of $\mathrm{Co}(\mathrm{OAc})_{2}$ or $\mathrm{CoI}_{2}$ (Table 3, entries $1-3)$. Therefore, we decided to reinvestigate the catalytic system for this type of substrate. The catalytic system $\mathrm{CoI}_{2}, \mathrm{Zn}$, dppe and $\mathrm{ZnI}_{2}$ was found competent to give cycloadduct 5a (69\%) along with small amount of $\mathbf{6 a}$ (11\% yield) (entry 4$)$. It turned out that the use of $\mathrm{Co}(\mathrm{OAc})_{2}$ instead of $\mathrm{CoI}_{2}$ led to a substantial decrease of the activity with only $10 \%$ of isolated cycloadduct $5 \mathbf{a}$ and $16 \%$ of $6 \mathbf{a}$ (entry 5). Additional experiments proved the need of $\mathrm{ZnI}_{2}$ that upgraded the efficiency of the cobalt-based catalyst but did not exhibit any activity itself (entries 6-8). Having in hands the optimized reaction conditions, several substituted dienynes 4 have been tested (Table 4). Despite a good diastereoselectivity, the catalytic system exhibited a reduced activity $C$ - and $O$ tethered dienynes and only low yields of $\mathbf{5 b}$ and $\mathbf{5 c}$ were obtained along with higher quantities of aromatic products (entries 2 and 3 ). For $4 \mathbf{d}$ bearing a phenyl substituent at the terminal position of the dienic moiety, only traces of cycloadduct $\mathbf{4 d}$ were isolated (entry 4) whereas with the $O$-tethered analogous $4 \mathbf{e}$ a better yield compared to dienyne $4 \mathbf{c}$ was reached (entry 5). Finally, with trimethylsilyl-substituted dienyne $\mathbf{4 f}$ the catalytic system led to the formation of $72 \%$ of the expected cycloadduct $\mathbf{5 f}$ and only $10 \%$ of oxidized product $\mathbf{6 f}$ (entry 6 ).
Table 3. Optimization of reaction conditions for substituted dienyne $\mathbf{4} \mathbf{a}^{\mathrm{a}}$

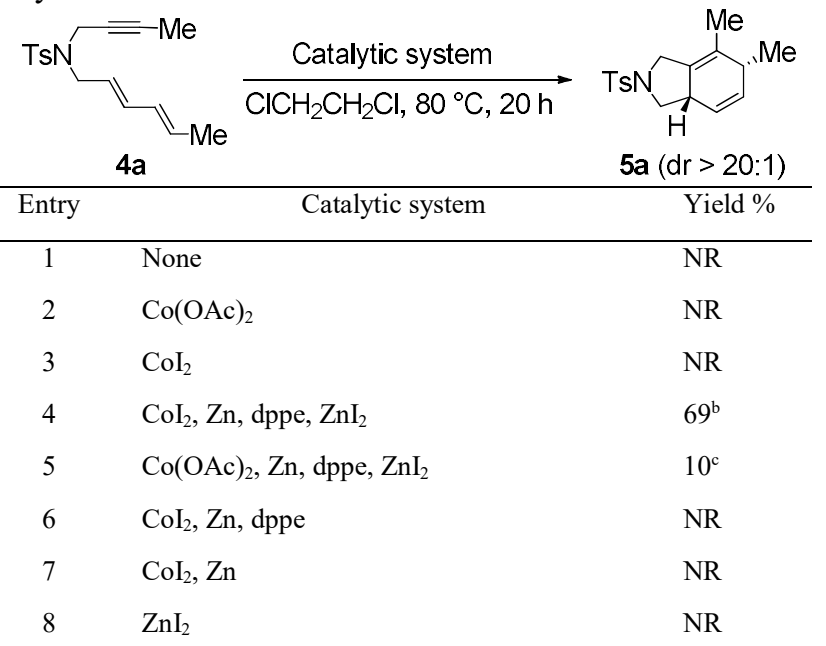

${ }^{\mathrm{a}}$ Conditions: $[\mathrm{Co}](5 \mathrm{~mol} \%), \mathrm{Zn}(15 \mathrm{~mol} \%)$, dppe $(5 \mathrm{~mol} \%), \mathrm{ZnI}_{2}(10 \mathrm{~mol} \%)$, dienyne 4a $(0.5 \mathrm{mmol}), \mathrm{ClCH}_{2} \mathrm{CH}_{2} \mathrm{Cl}(2 \mathrm{~mL}), 80^{\circ} \mathrm{C}, 20 \mathrm{~h} . \mathrm{NR}=\mathrm{No}$ Reaction;

${ }^{\mathrm{b}} 11 \%$ of oxidized product $3 \mathbf{a}$ was also isolated.

c $16 \%$ of $6 \mathbf{a}$.<smiles>Cc1ccccc1CN1CCNC1</smiles>

Table 4. 4 Scope investigation of cobalt-mediated intramolecular Diels-Alder cycloadditions of substituted dienynes $\mathbf{4}^{\mathrm{a}}$
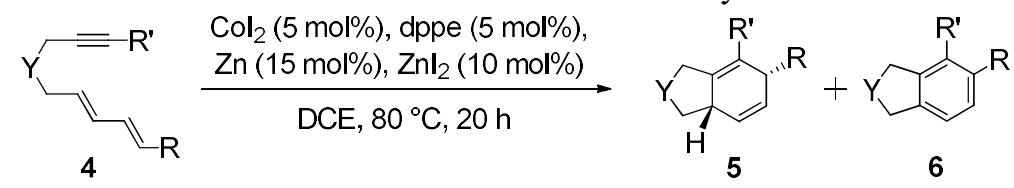

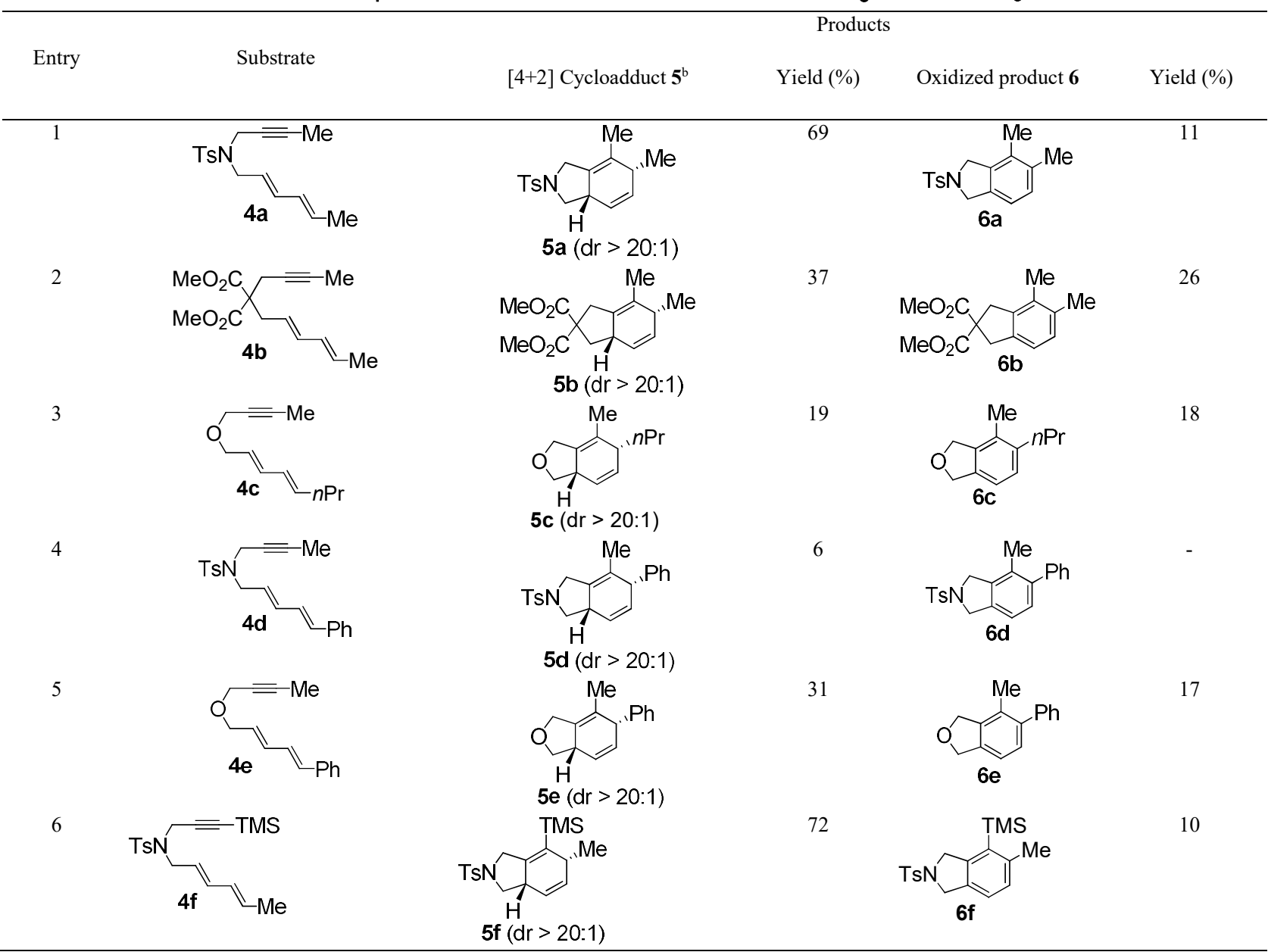


${ }^{\mathrm{b}}$ Major diastereomer depicted.

In summary, cobalt-based catalysts promoted the intramolecular [4+2] cycloaddition of dienynes. An important difference has been noticed as a function of substrates structure. With dienynes containing a terminal alkyne moiety, reactions performed without catalyst gave the expected cycloadducts along with substantial amounts of products resulting from their dehydrogenation. The use of a cobalt salt as catalyst; here the best was found to be sole $\mathrm{Co}(\mathrm{OAc})_{2}$; improved slightly the yields of [4+2] cycloadducts but made reactions cleaner by lowering the oxidation process whereas unwanted resulting dimerization ${ }^{16}$ can be circumvent by the use of degassed solvents. With dienynes possessing a substituent on the alkyne pattern, no reaction occurred without cobalt and even $\mathrm{ZnI}_{2}$ as Lewis acid was required to activate the catalyst. Once again, the nature of the tether as well as the one of the substituents on both alkyne and diene moieties were found to strongly influence the outcome of the highly diastereoselective [4+2] cycloadditions. The development of more active cobaltbased catalysts is currently underway in our laboratory.

\section{Acknowledgments}

This work was supported by the Ministère de l'Enseignement Supérieur et de la Recherche (B. B. Ph.D. grant), the CNRS, AMU, and Centrale Marseille.

\section{Supplementary Material}

Supplementary data associated with this article can be found, in the online version, at.

\section{References and notes}

1. For reviews reporting applications in synthesis, see: (a) Stathakis, C. I.; Gkizis, P. L.; Zografos, A. L. Nat. Prod. Rep. 2016, 33, 1093-1117; (b) Ardkhean, R.; Caputo, D. F. J.; Morrow, S. M.; Shi, H.; Xiong, Y.; Anderson, E. A. Chem. Soc. Rev. 2016, 45, 1557-1569; (c) Fensterbank, L.; Malacria, M. Acc. Chem. Res. 2014, 47, 953-965; (d) Rudolph, M.; Hashmi, A. S. K. Chem. Soc. Rev. 2012, 37, 2448-2462; (e) Furstner, A. Chem. Soc. Rev. 2009, 38, 3208-3221; (f) Nicolaou, K. C.; Snyder, S. A.; Montagnon, T.; Vassilikogiannakis, G.; Angew. Chem. Int. Ed. 2002, 41, 1668-1698.

2. (a) Trost, B. M. Acc. Chem. Res. 2002, 35, 695-705; (b) Trost, B. M. Angew. Chem. Int. Ed. 1995, 34, 259-281; (c) Trost, B. M. Science 1991, 254, 1471-1477.

3. For reviews on transition metal catalyzed cycloisomerisations, see: (a) Dorel, R.; Echavarren, A. M. Chem. Rev. 2015, 115, 9028-9072; (b) Obradors, C.; Echavarren, A. M.; Acc. Chem. Res. 2014, 47, 902-912; (c) Yamamoto, Y. Chem. Rev. 2012, 112, 4736-4769; (d) Michelet, V.; Toullec, P. Y.; Genêt, J.-P. Angew. Chem. Int. Ed. 2008, 47, 4268-4315; (e) Aubert, C.; Buisine, O.; Malacria, M. Chem. Rev. 2002, 102, 813-834.

4. For asymmetric processes, see: (a) Marinetti, A.; Jullien, H.; Voituriez, A. Chem. Soc. Rev. 2012, 41, 4884-4908; (b) Watson, I. D. G.; Toste, F. D. Chem. Sci. 2012, 3, 2899-2919; (c) Fairlamb, I. J. S. Angew. Chem. Int. Ed. 2004, 43, 1048-1052.

5. Wender, P. A.; Jenkins, T. E. J. Am. Chem. Soc. 1989, 111, 6432-6434

6. Jolly, R. S.; Luedtke, G.; Sheehan, D.; Livinghouse, T. J. Am. Chem. Soc. 1990, 112, 4965-4966.

7. McKinstry, L.; Livinhouse, T. Tetrahedron 1994, 50, 6145-6154.

8. (a) Gilbertson, S. R.; Hoge, G. S. Tetrahedron Lett. 1998, 39, 2075-2078; (b) Gilbertson, S. R.; Hoge, G. S.; Genov, D. G. J. Org. Chem. 1998, 63, 10077-10080; (c) Wang, B.; Cao, P.; Zhang, X. Tetrahedron Lett. 1998, 39, 2075-2078; (d) Motoda, D.; Kinoshita, H.; Shinokubo, H.; Oshima, K. Angew. Chem. Int. Ed. 2004, 43, 1860-1862; (e) Yoo, W.-J.; Allen, A.; Villeneuve, K.; Tam, W. Org. Lett. 2005, 7, 5853-5856; (f) DeBoef, B.; Counts, W. R.; Gilbertson, S. R. J. Org. Chem. 2007, 72, 799-804; (g) Aikawa, K.; Akutagawa, S.; Mikami, K. J. Am. Chem. Soc. 2006, 128, 12648-12649; (h) Shintani, R.; Sannohe, Y.; Tsuji, T.; Hayashi, T. Angew. Chem. Int. Ed. 2007, 46, 7277-7280; (i) Lee, S. I.; Park, S. Y.; Park, J. H.; Chung, Y. K.; Han, J. W. Bull. Korean Chem. Soc. 2007, 28, 1919-1920; (j) Gómez, Kamber, N. E.; Deschamps, N. M. Cole, A. P.; Wender, P. A.; Waymouth, R. M. Organometallics 2007, 26, 4541-4545; (k) Canlas, G. M. R.; Gilbertson, S. R. Chem. Commun. 2014, 50, 50075010 .

9. Shibata, T.; Takasaku, K.; Takesue, Y.; Hirata, N.; Takagi, K. Synlett 2002, 1681-1682.

10. Kim, S. M.; Park, J. H.; Chung, Y. K. Chem. Commun. 2011, 47, 67196721.

11. (a) Röse, P.; Hilt, G. Synlett 2016, 48, 463-492; (b) Amatore, M.; Aubert, C.; Malacria, M.; Petit, M. In Science of Synthesis, Vol. 1 Update 2012/3, Pliekter, B., Ed.; Thieme: Stuttgart, 2012, 1-121; (c) Hess, W., Treutwein, J.; Hilt, G. Synthesis 2008, 22, 3537-3562.

12. For selected examples, see: (a) Kuttner, J. R.; Warratz, S.; Hilt, G. Synthesis 2012, 44, 1293-1303; (b) Pünner, F.; Hilt, G. Chem. Commun. 2012, 48, 3617-3619; (c) Hilt, G.; Hengst, C. J. Org. Chem. 2007, 72, 7337-7342; (d) Hilt, G.; Lüers, S.; Harms, K. J. Org. Chem. 2004, 69, 624-630.

13. [4+2] cycloadducts were observed as side products in intramolecular Pauson-Khand reactions of dienynes, see: (a) Park, K. H.; Choi, S. Y.; Kim, S. Y.; Chung, Y. K. Synlett 2006, 527-532; (b) Choi, S. Y.; Lee, S. I.; Park, K. H.; Chung, Y. K. Synlett 2007, 1857-1862; For an unsuccessful attempt, see reference $8 \mathrm{e}$.

14. (a) Achard, M.; Tenaglia, A.; Buono, G. Org. Lett. 2005, 7, 2353-2356; (b) Toselli, N.; Martin, D.; Achard, M.; Tenaglia, A.; Bürgi, T.; Buono, G. Adv. Synth. Catal. 2008, 350, 280-286; (c) Clavier, H. Le Jeune, K.; De Riggi, E.; Tenaglia, A.; Buono, G. Org. Lett. 2011, 13, 308-311.

15. Lower diastereomeric ratios were observed with substrates containing little impurities.

16. For a more detailed discussion on the formation of dimers using rhodium-based catalysts, see: reference $8 \mathrm{~b}$.

17. See the supporting information.

18. For a rare example of thermal intramolecular [4+2] cycloaddition of dienyne, see: Karabiyikoglu, S.; Merlic, C. A. Org. Lett. 2015, 17, 4086489 . 